\title{
Students' Psychological Adjustment and Perceived Mental Healthcare Needs During Pandemic Covid-19
}

\author{
NH Marmaya, N Wee, NA Abdul Razak, NE Alias, WL Koe
}

To Link this Article: http://dx.doi.org/10.6007/IJARBSS/v11-i12/11865

DOI:10.6007/IJARBSS/v11-i12/11865

Received: 20 October 2021, Revised: 23 November 2021, Accepted: 06 November 2021

Published Online: 13 December 2021

In-Text Citation: (Marmaya et al., 2021)

To Cite this Article: Marmaya, N., Wee, N., Razak, N. A., Alias, N., \& Koe, W. (2021). Students' Psychological Adjustment and Perceived Mental Healthcare Needs During Pandemic Covid-19. International Journal of Academic Research in Business and Social Sciences, 11(12), 1116-1121.

Copyright: @ 2021 The Author(s)

Published by Human Resource Management Academic Research Society (www.hrmars.com)

This article is published under the Creative Commons Attribution (CC BY 4.0) license. Anyone may reproduce, distribute, translate and create derivative works of this article (for both commercial and non0-commercial purposes), subject to full attribution to the original publication and authors. The full terms of this license may be seen at: http://creativecommons.org/licences/by/4.0/legalcode

Vol. 11, No. 12, 2021, Pg. $1116-1121$

Full Terms \& Conditions of access and use can be found at http://hrmars.com/index.php/pages/detail/publication-ethics 


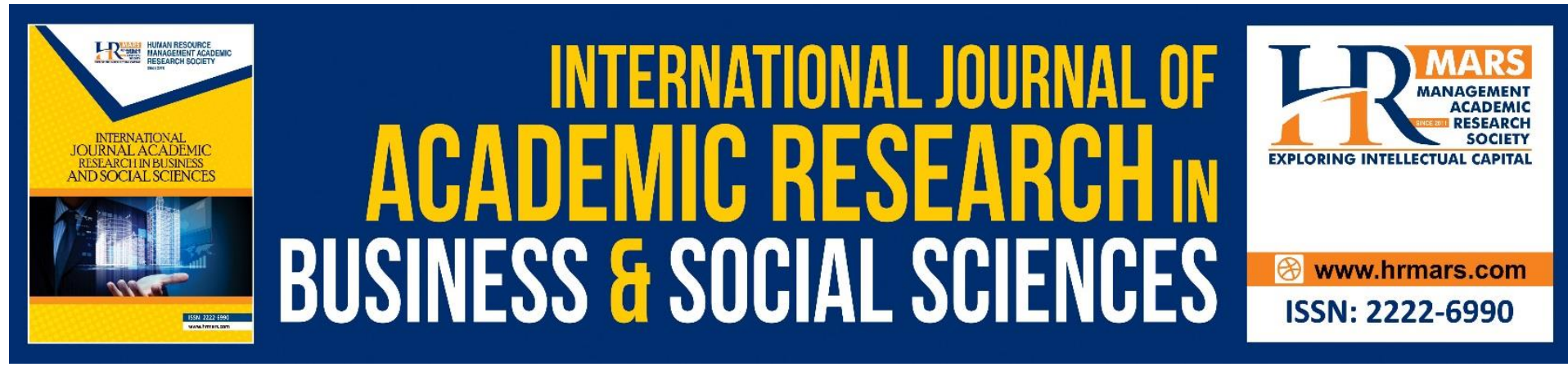

\title{
Students' Psychological Adjustment and Perceived Mental Healthcare Needs During Pandemic Covid-19
}

\begin{abstract}
${ }^{1} \mathrm{NH}$ Marmaya, ${ }^{2} \mathrm{~N}$ Wee, ${ }^{2} \mathrm{NA}$ Abdul Razak, ${ }^{2} \mathrm{NE}$ Alias, ${ }^{2} \mathrm{WL}$ Koe ${ }^{1}$ Faculty of Business and Management, 110 Off Jalan Hang Tuah, 75300 UniversitiTeknologi MARA Kampus Bandaraya Melaka, Malaysia, Centre for Islamic Philantrophy and Social Finance (CIPSF), Integrative Pharmacogenomics Institute (iPROMISE), Level 7, FF3 Building, UiTM Puncak Alam Campus, Bandar Puncak Alam, 42300 Puncak Alam, Selangor, Malaysia, ${ }^{2}$ Faculty of Business and Management, 110 Off Jalan Hang Tuah, 75300 UniversitiTeknologi MARA Kampus Bandaraya Melaka, Malaysia
\end{abstract}

\begin{abstract}
This study explores the level of psychological adjustment and perceived mental healthcare needs among university students in Malaysia. A quantitative method was adopted in this study and responses from 250 university students in Malaysia. This result shows most of the students' psychological adjustment were good however, the students still need mental healthcare from counselor. This study adopt a cross-sectional research design and longitudinal research design should be done for a better result. This empirical study attempts to enrich the understanding of the psychological adjustment and perceived mental healthcare needs among university students during pandemic covid 19 within Malaysian context.
\end{abstract}

\section{Introduction}

The shocking news that gives a huge impact on the whole world of the new virus from Wuhan, China. The virus called SARS-CoV-2 (WHO, 2020). This coronavirus disease (COVID-19) been discovered in December 2019 in Wuhan, China, where at the beginning the virus was unidentified in the human body and then officially reported it is SARS-CoV-2 (WHO, 2020). Due to the pandemic, most of businesses closed. This is to restrict the movement of people to control the spread of the virus called Movement Control Order (MCO). When the MCO begins, the citizen is being reported affecting a mental health problem in much of the challenges of difficulty to cope to stay at home for months and the mixed feeling of stress, anxiety, fear, suicidal, and helplessness. In Malaysia, the statistics from January 1 to June 18 2021 revealed that 89.4 per cent $(109,806$ out of 122,328 calls $)$ were related to mental health issues that required emotional and psychological support. The helplines were managed by the Malaysia Ministry of Health (MOH), the Ministry of Women, Malaysia, Family and Community Development (MWFCD) and the Department of Islamic Development (JAKIM) of Malaysia. The factors that led to mental illness are the loss of loved ones, new COVID-19 variants, loss of jobs and income, loss of a place of dependence, ongoing financial distress and family issues arising from long isolation. 
The meaning of the adjustment in psychology refers to the changes in life that are made continuously when one has a chronic illness, it is not static but dynamic. While based on the past research by Paramjinang et al (2015), adjustment is the process of finding and adopting modes of behavior suitable to the environment or the change in the environment. COVID-19 pandemic is causing the psychological responses are randomly changing like anxiety and distress. According to the World Health Organization (2020), stated that the crisis of COVID19 outbreak is generating stress throughout the population. Perceived Mental Healthcare is a state that by technologies, such as application of internet should have new psychosocial prevention and intervention, in which can be integrated with all health organizations, mental health authorities, governments, and hospitals with their staff as a psychiatrist, psychologists, community physicians, and social workers as well as medical practitioners, need to combine the early intervention and will do the rehabilitation services onwards (Dubey et al., 2020). According to the Ministry of Health, Malaysia (MOH) (2020), stated that it is common for individuals to have mixed feelings like stress, anxiety, worry, and fear during this pandemic of Coronavirus Diseases 2019 (COVID-19).

The development of technology has remarkably benefited many industries including the educational sector. The evolution of the internet technology has complemented the delivery of lessons. Nowadays, the use of nonconventional methods of teaching is very relevant and of great demand as the group of learners in higher learning institutions are the technology natives (Chung et al, 2020). Engaging students to do e-learning was a choice given, whether to implement that option in the learning environment or stick to being in the four walls method (Abdelmalak, 2015). Open and Distance Learning (ODL) has been implemented in Malaysian public and private universities during pandemic covid 19. During pandemic, its implementation has been accelerated globally at an unprecedented speed and haste. The synchronous (teaching and communicating with students in real time online) and asynchronous (recorded lectures or posted assignments online) added to the compounding challenges, especially for students with internet unavailability and poor connectivity (Lowenthal et al., 2020). According to Elmer et al (2020), the manifestations of stress, anxiety, loneliness and depression among students were amplified post the COVID-19 crisis. The findings by Arumugam et al (2021) indicated students within Malaysian public and private universities were profoundly affected during the lockdown, resulting in diminished mental states. Remote learning being foreign for many and needing to accommodate new learning styles in a short span of time contributed to emphasized anxiety and stress. This was unfavorable to the academic performance of students. The objective of this study is:

- $\quad$ To find out the level of psychological adjustment and level of perceived mental health care among students during Pandemic Covid 19.

Hence, the paper has addressed these questions:

- What is the level of psychological adjustment among students during Pandemic Covid 19.

- What is the level of perceived mental health care among students during Pandemic Covid 19.

\section{Methodology}

A convenience sampling was applied in this study. Data for the study was collected through the sample of 250 respondents who are university students and experiencing online distance learning (ODL). The Mental Health Inventory (5 items) (Davies et al., 1988) is used to measure students' level of psychological adjustment. Item responses are obtained using a 6-point scale 
from 1 (none of the time) to 6 (all of the time). Question 1, 3 and 5 are negatively worded. Perceived Mental Health Care Needs questionnaire developed by Roy et al, (2020) is used to measure students'level of perceived mental healthcare needs during ODL. The questionnaire has 5 items (eg., Do you think it would be nice to talk to someone about your worries for the COVID 19 pandemic?) on a 5-point Likert scale from 1 (Strong disagree) to 5 (strongly disagree). A detailed description of the demographic profile of the respondents shows that majority of the respondents who completed the questionnaire were male $55 \%$, with females accounting for $45 \%$. Most of respondents are pursuing their bachelor degree followed by diploma level.

\section{Result}

Table 1: Psychological Adjustment during ODL

\begin{tabular}{|l|l|l|l|}
\hline No & \multicolumn{1}{|c|}{ Items } & \multicolumn{1}{|c|}{ Mean } & \multicolumn{1}{|c|}{$\begin{array}{c}\text { Std. } \\
\text { Deviation }\end{array}$} \\
\hline 1. & $\begin{array}{l}\text { How much of the time during the past } \\
\text { month, have you been a very nervous } \\
\text { person? }\end{array}$ & 2.757 & 1.33 \\
\hline 2. & $\begin{array}{l}\text { How much of the time during the past } \\
\text { month, have you felt calm and peaceful? }\end{array}$ & 3.529 & 1.008 \\
\hline 3. & $\begin{array}{l}\text { How much of the time during the past } \\
\text { month, have your felt down-hearted and } \\
\text { blue? }\end{array}$ & 2.995 & 1.194 \\
\hline 4. & $\begin{array}{l}\text { How much of the time during the past } \\
\text { month, have you been a happy person? }\end{array}$ & 3.752 & 1.030 \\
\hline 5. & $\begin{array}{l}\text { How much of the time during the past } \\
\text { month, have you felt so down in the dumps } \\
\text { that nothing could cheers you up? }\end{array}$ & 2.594 & 1.401 \\
\hline
\end{tabular}

*Psychological Adjustment questions are based on the 5 Likert scales ( 1 = None of the time, $2=$ A little of the time, $3=$ Some of the time, $4=A$ good bit of the time and $5=$ All of the time) 
Table 1 shows that most of the students are happy and felt calm and peaceful and cheers during ODL.

Table 2: Perceived Mental Healthcare Needs

\begin{tabular}{|l|l|l|l|}
\hline No & \multicolumn{1}{|c|}{ Items } & \multicolumn{1}{|c|}{ Mean } & \multicolumn{1}{|c|}{$\begin{array}{c}\text { Std. } \\
\text { Deviation }\end{array}$} \\
\hline 1. & $\begin{array}{l}\text { Do you think it would be nice to talk to } \\
\text { someone about your worries about the } \\
\text { COVID-19 viral epidemic? }\end{array}$ & 3.970 & 0.961 \\
\hline 2. & $\begin{array}{l}\text { Do you think it is necessary to get mental } \\
\text { health help if one panics instead of the } \\
\text { Pandemic situation? }\end{array}$ & 3.985 & 1.048 \\
\hline 3. & $\begin{array}{l}\text { Do you think it would be beneficial if mental } \\
\text { health professionals help people in dealing } \\
\text { with the current CoVID-19 pandemic } \\
\text { situation? }\end{array}$ & 4.321 & 0.828 \\
\hline 4. & $\begin{array}{l}\text { Will you suggest people for obtaining mental } \\
\text { health help to people who are highly affected } \\
\text { by the coVID-19 pandemic? }\end{array}$ & 4.237 & 1.008 \\
\hline
\end{tabular}

*Perceived Mental Health Needs care are based on 5-Point likert scale (1 Strongly disagree and 5 Strongly agree)

Table 2 shows that most of the students need mental healthcare during ODL which they need help from mental health professional like counselor from their university. The students agree to talk to someone about their worries on Covid-19, and they agree that it would be beneficial if mental health professionals help them in dealing with the current Covid 19 pandemic situation.

\section{Discussion}

The results shows that most of the students are well adjust their psychology during ODL. This may be due to their experience using ODL for more than one year. It is shown that they are well in adapting their life to a new environment in learning experience and also are good at changing, adapting, and controlling their minds to the new environment. The other factors to this may be due to the supportive by the lecturers in their lesson delivery and the ODL platforms used. However, most of the students still need mental healthcare during ODL. Most of the students felt the need for the professional help from mental health experts to deal with emotional issues and other psychological issues during ODL.

\section{Contribution and Limitation}

The findings of this study have managed to unravel and contribute new understanding related to psychological adjustment and perceived mental healthcare needs among students within Malaysian context that gives significant implications to the existing body of knowledge. Practically, top management and lecturers of the university need to understand how important mental healthcare support to their students. This can be done through accessible counseling services to all students to ensure that students with various problems access these services easily. Lecturers also need always support and motivate students during class. Class also should be more flexible and creative in online teaching for example, expanding the audience to reach through Massive Open Online Courses (MOOCs) and fun online games and quizzes during class (Ghazali et al., 2020). There are a few limitations that should be 
recognized that may provide for future research. Firstly, this study adopts a cross-sectional research design and examines the opinions of students at only one point in time. Longitudinal research design should be done for a better result.

\section{References}

Abdelmalak, M. (2015). Web 2.0 Technologies and Building Online Learning Communities: Students' Perspectives. Online Learning, 19(2), n2.

Arumugam, N., Ramasamy, V. (Resh), Suppiah, P. C., \& Segarmurthy, M. V. (2021). Mental Health Among Malaysian University Students Amidst Lockdown. International Journal of Academic Research in Progressive Education and Development, 10(2), 1081-1095.

Chung, E., Noor, N. M., \& Mathew, V. N. (2020a). Are You Ready? An Assessment of Online Learning Readiness among University Students. International Journal of Academic Research in Progressive Education and Development, 9(1), 301-317. DOI:

Elmer, T., Mepham, K., \& Stadtfeld, C. (2020). Students under lockdown: comparisons of students' social networks and mental health before and during the COVID-19 crisis in Switzerland. PLOS One, 15(7), 1-22. https://doi.org/10.1371/journal.pone.0236337

Lowenthal, P., Borup, J., West, R., \& Archambault, L. (2020). Thinking beyond zoom: using asynchronous video to maintain connection and engagement during the COVID-19 pandemic. Journal of Technology and Teacher Education, 28(2), 383-391.

Paramjinang, M. (2015). Communication Skills for Personality Development in Library Profession. Asian Journal of Multidisciplinary Studies. 3. 64-68.

Davies, A. R., Sherbourne, C. D., Peterson, J. R., and Ware, J., J. E. (1988). Scoring manual: Adult health status and patient satisfaction measures used in RAND's health insurance experiment. Santa Monica: The RAND Corporation

Ghazali, N., Nordin, M. S., Abdullah, A., \& Ayub, A. F. M. (2020). The Relationship between Students' MOOC-efficacy and Meaningful Learning. Asian Journal of University Education, 16(3), 89- 101. 